\title{
IMPACT OF PORTLAND CEMENT ON GROWTH OF BEAN CROPS
}

\author{
Raheela IQBAL ${ }^{1}$, Muhammad Zafar IQBAL ${ }^{1}$, Muhammad SHAFIQ ${ }^{1 *}$ \\ ${ }^{1}$ Department of Botany, University of Karachi, Karachi-75270 - Pakistan \\ *Corresponding author. E-mail: shafiqeco@yahoo.com
}

\begin{abstract}
Cement manufacturing industries are responsible for environmental degradation at regional and global level. This study was undertaken the effect of port land cement on three different legume crops in pot. The cement treatment differently influenced on germination and biomass of all studied bean crops. Statistically, the root length of Vigna radiata was decreased at $0.50 \mathrm{~g}$ cement level. The cement treatment at similar level significantly reduced shoot and seedling length of $V$. mungo. The total seedling dry weight of $V$. unguiculata was significantly affected with cement treatment at $1.0 \mathrm{~g}$. The sprinkled treatment at 2 g reduced tolerance index in seedlings of $V$. unguiculata, $V$. mungo and $V$. radiata, respectively.
\end{abstract}

Keywords: bean, cement pollution, pulse, seedling growth, tolerance, yield.

\section{Introduction}

The addition of organic and inorganic compounds in biosphere due to industrial activities produced damaging impact on plant growth. The alteration in the quality of air may leave profound effects on plant growth [JOSHI \& al. 2009] and long exposure effect on lung function [MEO \& al. 2017]. Cement is extensively used for construction and infrastructures all around the worldwide. The cement plants are a source of pollution [EKINCI \& al. 2020]. Soil contamination by potentially toxic elements showed adverse environmental impacts [PALANSOORIYA \& al. 2020] on living organism.

Cement has global impact on environment and is an important source of greenhouse gas emissions [SHEN \& al. 2014] and vegetation [FAKHRY \& MIGAHID, 2011]. The decrease in number of species near cement plant, stomatal clogging in Inula grantioides Boiss., decrease in leaf size for Sida acuta Burm f., and seedling height of Datura innoxia Mill. and chlorophyll contents of Vigna unguiculata (L.) Walp. due to cement pollution was recorded [SHAFIQ \& IQBAL, 1987; ABDULLAH \& IQBAL, 1991; AYANBAMIJI \& OGUNDIPE, 2010]. The cement pollution also influence on plant growth, trace elements, chloroplast pigmentation, biomass production and nature, structure and composition of vegetation [FAKHRY \& MIGHAHID, 2011; SHAFIQ \& IQBAL, 2012; SHAFIQ \& al. 2019].

Cowpea, black gram and mung bean are an important nutritional legume crops [KONGJAIMUN \& al. 2013; IRITI \& VARONI, 2017; KUMAR \& al. 2017] and have the ability to grow in harsh environmental conditions [WIN \& OO, 2016]. Vigna mungo (L.) Hepper is an annual herbaceous legume crop, cultivated for its edible seeds. Mash bean is widely cultivated throughout the tropics [EFLORA, 2018]. The ecologist are researching on the impact of environmental pollutants on plant growth. A significant increase of cement in the environment is resulting air pollution problem in Pakistan and affecting productivity of agricultural crops. 
The industrialization, rise of life quality of regions and strategies for economic prosperity leaded to an imminent increase of the quantity of eliminated waste [TARO \& COMAN, 2020] and pollution [JOSHI \& SWAMI, 2009]. Lucky Cement Factory was founded in 1996 [REUTERS, 2008]. Few studies have examined cement pollution impact on plant growth globally and less on this aspect on bean crop has been done in Pakistan. Therefore, in this experiment, the impact of Portland cement on growth of different bean crops was evaluated to find the level of toxicity and tolerance limit of bean to portland cement.

\section{Material and methods}

The sample of Portland cement was collected from lucky cement factory which is located near hub chowky, Blochistan, Pakistan. The certified seeds of bean crops (Vigna unguiculata, Vigna mungo and Vigna radiata) were purchased from the local super store and immersed for $1 / 2$ an hour in distilled water to breakup seeds dormancy. The garden loam soil was passed through $2.0 \mathrm{~mm}$ sieve and was transferred in plastic pots having diameter $7.3 \mathrm{~cm}$ and $9.6 \mathrm{~cm}$ height. The filter paper was kept at bottom of pot having a small hole to minimize loss of chemical from soil. The ratio of garden soil was one part manure and two parts fine sand. Ten seeds were sown in each pot at $1 \mathrm{~cm}$ depth and irrigated with tap water with five replicates. Three best seedlings of same height were used for sprinkled treatment of cement at $0,0.50,1.0,1.5,2.0 \mathrm{~g}$ level on the aerial parts twice in a week. Height of plants were measured before sprinkling and pots positions were changed weekly to avoid any greenhouse effect. The experiment design was completely randomized for seven weeks. All the plants were removed from pots and washed with water for measurement of root, shoot and seedling length. The seedlings were dried in oven at $80^{\circ} \mathrm{C}$ for 24 hours to record total plant dry weight.

The leaf area ratio, root/shoot ratio, leaf weight ratio and specific leaf area were described as given by REHMAN \& IQBAL (2009).

An index of tolerance was determined by the following formula:

Mean root length in cement treatment / Mean root length in without cement treatment X 100 .

Analysis of Variance (ANOVA) and Duncan Multiple Range Test (DMRT) at $\mathrm{p}<0.05$ was carried out on personnel computer using software packages SPSS version 10 .

\section{Results and discussion}

Air pollution by cement has become a major threat to growth of plant [DEVARAJAN \& al. 2018]. In present study there were variable response of cement pollution treatment on beans growth and tolerance indices were recorded (Table 1-3; Figures 1-2). The difference in seedling growth of bean were might be associated with increase in level of cement pollution treatment. Root growth responds incredibly dynamically in abio-stress conditions. The treatment at $0.5 \mathrm{~g}$ level significantly $(\mathrm{p}<0.05)$ affected root growth of Vigna radiata (Table 1$)$. The toxic effects are in agreement of other researchers' findings. The negative effects of $\mathrm{O}_{3}, \mathrm{SO}_{2}$ and $\mathrm{NO}_{2}$ emissions from cement industry on seedling height of Datura innoxia Mill. and reduction in yield of cowpea plant were recorded also by different researchers [SALAMA \& al. 2011; ADDO \& al. 2013]. Plant response varies between species of a given genus for morphological characteristics. Based on the difference of morphological parameters from the control the order of tolerance to cement pollution 0.50 g cement treatment produced significant effect on shoot growth of all bean. Cement treatment of $1.5 \mathrm{~g}$ significantly decreased seedling length of $V$. mungo and at $2.0 \mathrm{~g}$ positively decreased seedling height of mung bean (Table 2). ZARGARI \& SHOAR (2008) also reported similar results 
Raheela IQBAL \& al.

regarding toxic effects of cement dust on growth characteristics performances of Helianthus annuus L. The soluble pollutants of cement dust were considered responsible for inhibition in germination of Medicago sativa [LAFRAGÜETA \& al. 2014]. The treatment at $1.0 \mathrm{~g}$ level significantly affected total seedling dry weight of all bean crops. Similarly, decrease in phytomass of $V$. mungo due to exposure of cement kiln dust was investigated [PRASAD \& INAMDAR, 1990]. PANDEY \& KUMAR (1996) also confirmed he impact of cement dust pollution on biomass, chlorophyll, nutrients and grain characteristics of wheat.

A reduction in biomass of conifers to cement was due to cchanges in content of nutrient [MANDRE \& al. 1999]. Statistically the poor development in leaf area $\left(\mathrm{cm}^{2} \mathrm{~g}^{-1}\right)$ of $V$. radiata and $V$. unguiculata to cement treatment was noted (Table 3). Similarly, impact of dust particles depends on the amount of the dust responsible for the development of toxicity potential recorded [ $t$ UKOWSKI \& al. 2020].

Table 1. Seedling growth performance of Vigna radiata (L.) Wilczek in different levels $(0,0.5,1.0,1.5$ and $2.0 \mathrm{~g})$ of cement treatment.

\begin{tabular}{|c|c|c|c|c|c|}
\hline $\begin{array}{c}\text { Cement } \\
\text { treatments (g) }\end{array}$ & $\begin{array}{c}\text { Leaf area } \\
\mathrm{cm}^{2}\end{array}$ & $\begin{array}{c}\text { Root / shoot } \\
\text { ratio }\end{array}$ & $\begin{array}{c}\text { Leaf weight } \\
\text { ratio }\end{array}$ & $\begin{array}{c}\text { Specific leaf } \\
\text { area }\left(\mathrm{cm}^{2} \mathrm{~g}^{-1}\right)\end{array}$ & $\begin{array}{l}\text { Leaf area ratio } \\
\qquad\left(\mathrm{cm}^{2} \mathrm{~g}^{-1}\right)\end{array}$ \\
\hline 0 & $37.69 \mathrm{~b} \pm 1.27$ & $0.40 \mathrm{a} \pm 0.12$ & $0.41 \mathrm{a} \pm 0.02$ & $468.91 \mathrm{a} \pm 73.94$ & $187.06 a \pm 17.53$ \\
\hline 0.5 & $35.70 \mathrm{ab} \pm 3.92$ & $0.26 a \pm 0.09$ & $0.41 a \pm 0.02$ & $433.38 a \pm 48.29$ & $179.00 \mathrm{a} \pm 18.15$ \\
\hline 1.0 & $32.29 \mathrm{ab} \pm 2.48$ & $0.39 a \pm 0.08$ & $0.41 a \pm 0.05$ & $332.16 a \pm 41.77$ & $180.62 \mathrm{a} \pm 23.30$ \\
\hline 1.5 & $32.23 \mathrm{ab} \pm 3.07$ & $0.35 a \pm 0.04$ & $0.41 a \pm 0.03$ & $452.76 \mathrm{a} \pm 42.42$ & $178.11 \mathrm{a} \pm 24.72$ \\
\hline 2.0 & $27.46 a \pm 1.93$ & $0.33 a \pm 0.03$ & $0.41 a \pm 0.03$ & $451.35 a \pm 88.07$ & $179.05 \mathrm{a} \pm 25.40$ \\
\hline
\end{tabular}

Symbol used: \pm standard error $=$ Statistical significance determined by analysis of variance. Number followed by the same letter in the same column are not significantly different, according to Duncan's Multiple range test at $\mathrm{P}<0.05$.

Table 2. Seedling growth performance of Vigna mungo (L.) Hepper in different levels $(0,0.5,1.0,1.5$ and $2.0 \mathrm{~g})$ of cement treatment.

\begin{tabular}{|c|c|c|c|c|c|}
\hline $\begin{array}{l}\text { Cement } \\
\text { treatments } \\
(\text { (g) }\end{array}$ & $\begin{array}{l}\text { Leaf area } \\
\mathbf{c m}^{2}\end{array}$ & $\begin{array}{l}\text { Root / shoot } \\
\text { ratio }\end{array}$ & $\begin{array}{l}\text { Leaf weight } \\
\text { ratio }\end{array}$ & $\begin{array}{l}\text { Specific leaf area } \\
\qquad\left(\mathrm{cm}^{2} \mathrm{~g}^{-1}\right)\end{array}$ & $\begin{array}{l}\text { Leaf area ratio } \\
\qquad\left(\mathrm{cm}^{2} \mathrm{~g}^{-1}\right)\end{array}$ \\
\hline 0 & $18.65 a \pm 1.40$ & $0.22 \mathrm{a} \pm 0.12$ & $0.39 \mathrm{a} \pm 0.03$ & $166.93 a \pm 29.13$ & $62.58 \mathrm{a} \pm 7.44$ \\
\hline 0.5 & $17.82 \mathrm{a} \pm 1.95$ & $0.29 \mathrm{ab} \pm 0.09$ & $0.40 \mathrm{a} \pm 0.03$ & 409.79ab \pm 77.72 & $159.23 b \pm 22.09$ \\
\hline 1.0 & $17.13 a \pm 1.23$ & $0.32 \mathrm{ab} \pm 0.08$ & $0.37 a \pm 0.05$ & $437.33 \mathrm{ab} \pm 166.06$ & $138.21 \mathrm{ab} \pm 29.87$ \\
\hline 1.5 & $13.99 a \pm 1.76$ & $0.23 a \pm 0.04$ & $0.29 \mathrm{a} \pm 0.07$ & $537.78 \mathrm{~b} \pm 94.44$ & $148.72 \mathrm{ab} \pm 46.15$ \\
\hline 2.0 & $13.62 \mathrm{a} \pm 1.33$ & $0.45 b \pm 0.03$ & $0.40 \mathrm{a} \pm 0.01$ & $530.64 \mathrm{~b} \pm 77.60$ & $210.19 b \pm 28.28$ \\
\hline \multicolumn{6}{|c|}{$\begin{array}{l}\text { Symbol used: } \pm \text { standard error }=\text { Statistical significance determined by analysis of variance. Number followed } \\
\text { by the same letter in the same column are not significantly different, according to Duncan's Multiple range test } \\
\text { at } \mathrm{P}<0.05 \text {. }\end{array}$} \\
\hline
\end{tabular}

Table 3. Seedling growth performance of Vigna unguiculata (L.) Walp. in different levels $(0,0.5,1.0,1.5$ and $2.0 \mathrm{~g})$ of cement treatment.

\begin{tabular}{|c|c|c|c|c|c|}
\hline $\begin{array}{c}\text { Cement } \\
\text { treatments (g) }\end{array}$ & $\begin{array}{c}\text { Leaf area } \\
\mathrm{cm}^{2}\end{array}$ & $\begin{array}{c}\text { Root / shoot } \\
\text { ratio }\end{array}$ & $\begin{array}{c}\text { Leaf weight } \\
\text { ratio }\end{array}$ & $\begin{array}{l}\text { Specific leaf } \\
\text { area }\left(\mathrm{cm}^{2} \mathrm{~g}^{-1}\right)\end{array}$ & $\begin{array}{c}\text { Leaf area ratio } \\
\left(\mathrm{cm}^{2} \mathrm{~g}^{-1}\right)\end{array}$ \\
\hline 0 & $73.43 \mathrm{~b} \pm 5.04$ & $1.19 a \pm 0.10$ & $0.38 \mathrm{ab} \pm 0.01$ & $361.61 \mathrm{~b} \pm 40.34$ & $140.90 \mathrm{a} \pm 14.97$ \\
\hline 0.5 & $64.52 \mathrm{ab} \pm 1.52$ & $1.07 a \pm 0.07$ & $0.42 \mathrm{ab} \pm 0.01$ & $240.65 a \pm 24.24$ & $102.84 a \pm 6.69$ \\
\hline 1.0 & $58.74 a b \pm 9.10$ & $1.14 a \pm 0.11$ & $0.43 \mathrm{ab} \pm 0.01$ & $242.97 a \pm 40.19$ & $104.47 a \pm 15.47$ \\
\hline 1.5 & $52.63 a \pm 4.06$ & $1.44 a \pm 0.40$ & $0.45 b \pm 0.02$ & $232.25 a \pm 30.19$ & $105.10 \mathrm{a} \pm 14.12$ \\
\hline 2.0 & $61.03 a \pm 7.01$ & $0.97 a \pm 0.20$ & $0.36 a \pm 0.03$ & $298.52 \mathrm{ab} \pm 39.54$ & $103.54 a \pm 18.56$ \\
\hline
\end{tabular}


The seedlings of beans were tested for tolerance to cement (Figure 2). The studies showed selective sensitivity to cement treatment exposure among plant species. $0.50 \mathrm{~g}$ cement treatment showed high percentage of tolerance in $V$. radiata, $V$. mungo and $V$. unguiculata seedlings. The lowest percentage of tolerance for $V$. mungo (64.70\%), V. radiata (69.39\%) and V. unguiculata (90.99\%) was recorded with 2.0 g cement.
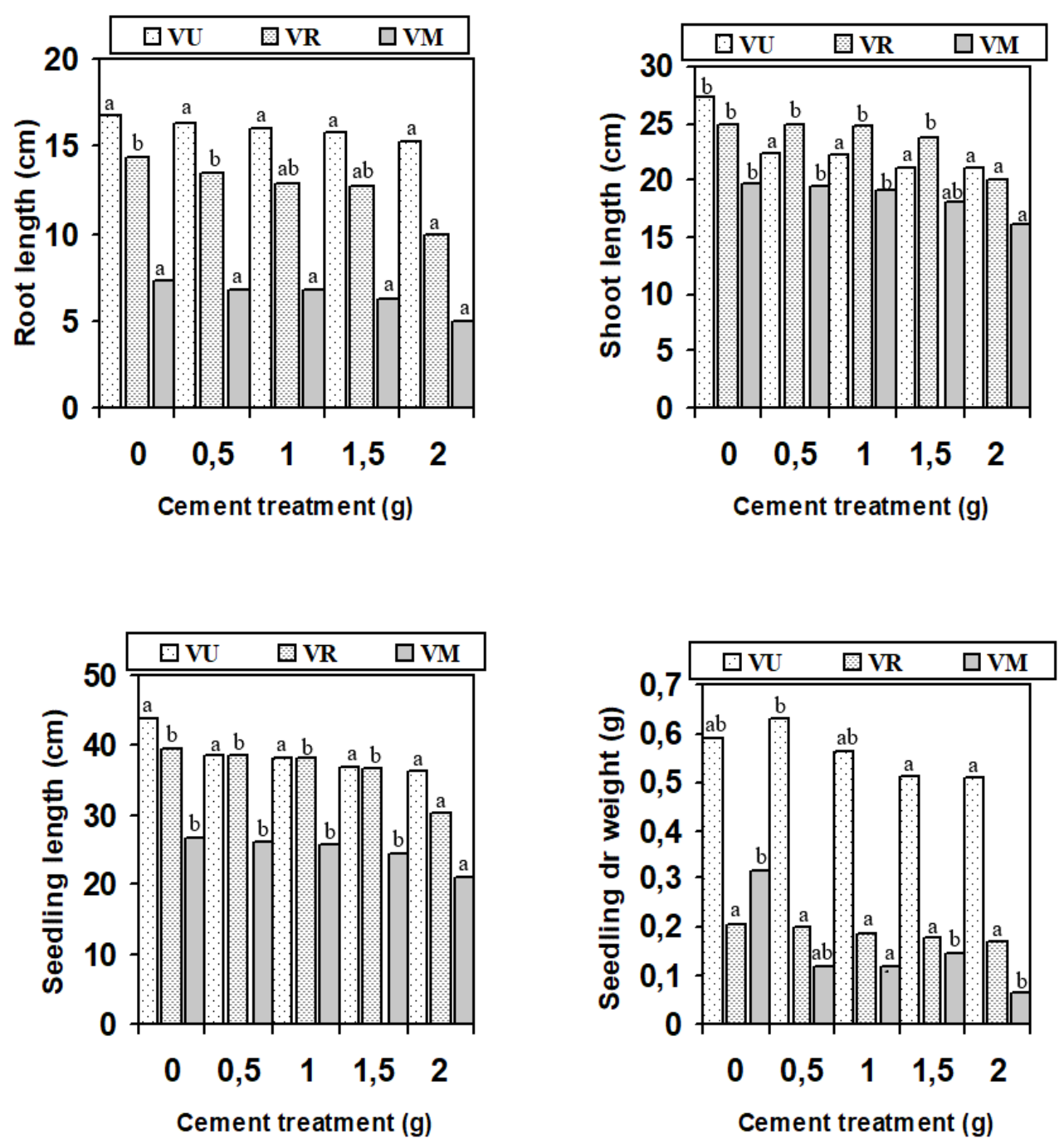

Figure 1. Effects of different level of cement treatment at 0, 0.5, 1, 1.5 and $2 \mathrm{~g}$ on root, shoot, seedling length and seedling dry weight $(\mathrm{g})$ of $\mathrm{VU}=$ Vigna unguiculata, $\mathrm{VR}=$ Vigna radiata, $\mathrm{VM}=$ Vigna mungo. Values followed by the same letters on same bar chart are not significantly different $(\mathrm{p}<0.05)$ according to Duncan's Multiple Range Test. 


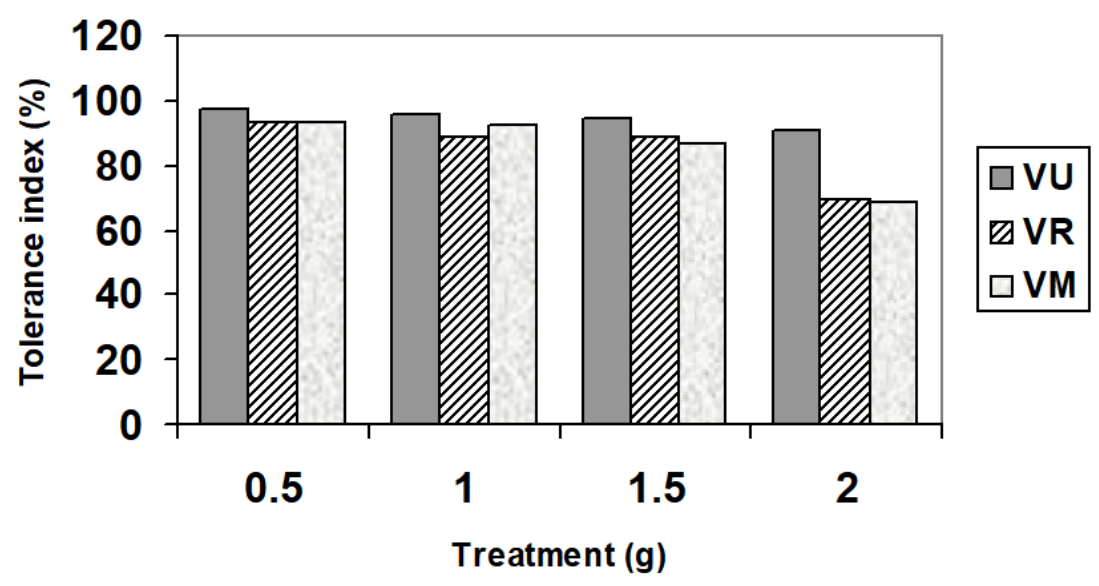

Figure 2. Tolerance indices of VU = Vigna unguiculata, $\mathrm{VR}=$ Vigna radiata, $\mathrm{VM}=$ Vigna mungo, against different level of cement treatment at $0.50,1.0,1.50$ and $2.0 \mathrm{~g}$.

\section{Conclusion}

The sprinkled treatment of Portland cement produced variable Portland cement toxic impact on seedling growth of bean crops. The response of bean plant to cement pollution varied between species of a genus. Plants also do not behave similar to pollutants and depends on level of tolerance and adaptation. The seedlings of $V$. unguiculata, V. radiata and V. mungo showed low percentage of tolerance to cement treatment at $2.0 \mathrm{~g}$.

\section{Notes on contributors}

Prof. Dr. Muhammad Zafar IQBAL, PhD, is ex-chairman department of Botany, University of Karahi. Prof. Dr. M. Zafar IQBAL has special interest in plant ecology and pollution / climatology / plant and environment / automobile pollution / industrial pollution and ecology and has published more than 180 scientific research papers in national and international scientific peer reviewed renowned scientific journals.

Raheela IQBAL is BS student in Botany.

Dr. Muhammad SHAFIQ, PhD, is a research scholar and have main interest in plant ecology and environmental pollution, phytosociology, heavy metal tolerance. He has published more than 110 scientific research papers in national and international scientific peer reviewed renowned scientific journals. He has also published books on "Impact of Automobile Pollutants on Plants" and "Poison Land. Vegetation of disturbed and polluted areas in Pakistan". He has also published few book chapters.

\section{Acknowledgements}

The authors sincerely acknowledged the experimental facilities provided by the Chairman, Department of Botany, University of Karachi. 


\section{References}

ABDULLAH C. M. \& IQBAL M. Z. 1991. Response of automobile, stone and cement particulate matters on stomatal clogging of plants. Geobios. 18: 196-202.

ADDO M. A., DARKO E. O., GORDON C. \& NYARKO B. J. B. 2013. Contamination of soils and loss of productivity of Cowpea (Vigna unguiculata L.) caused by cement dust pollution. International Journal of Research in Chemistry and Environment. 3(1): 272-282.

ALANSOORIYA K. N., SHAHEEN S. M., CHEN S. S., TSANG D. C. W., HASHIMOTO Y., HOU D., BOLAN N. S., RINKLEBE J. \& OK Y. S. 2020. Soil amendments for immobilization of potentially toxic elements in contaminated soils: A critical review. Environment International. 134: 105046. https://doi.org/10.1016/j.envint.2019.105046

AYANBAMIJI T. A. \& OGUNDIPE O. 2010. Effect of cement dust on the morphology and levels of some metals in Eleusine indica L. Guertn. and Sida acuta Burn. F. Bulletin of Pure and Applied Sciences. 29b(1): $37-45$.

DEVARAJAN R., NARENDRA K., RAM N. K. \& HANUMAPPA K. R. 2018. Study of morphological and germination parameters of legume crops Vigna mungo L. treated with cement dust. Alexandria Science Exchange Journal. 39(3): 419-431. https://doi.org/10.21608/ASEJAIQJSAE.2018.11257

EFLORA. 2018. Flora of Pakistan. www.Efloras.org. http://www.efloras.org/florataxon.aspx? flora id=5\&taxon id= 242426207. Accessed on 30 ${ }^{\text {th }}$ October, 2018.

EKINCI E., KAZANCOGLU Y. \& MANGLA S. K. 2020. Using system dynamics to assess the environmental management of cement industry in streaming data context. Science of the Total Environment. 715: 136948.

FAKHRY A. M. \& MIGAHID M. M. 2011. Effect of cement-kiln dust pollution on the vegetation in the Western Mediterranean Desert of Egypt. World Academy of Science Engineering and Technology. 81: 28-34.

IQBAL M. Z. \& SHAFIQ M. 2001. Periodical effect of cement dust pollution on the growth of some plant species. Turkish Journal of Botany. 25: 19-24.

IRITI M. \& VARONI E. 2017. Pulses, healthy, and sustainable food sources for feeding the planet. International Journal of Molecular Sciences. 18: 255. https://doi.org/10.3390/ijms18020255

JOSHI N., CHAUHAN A. \& JOSHI P. C. 2009. Impact of industrial air pollutants on some biochemical parameters and yield in wheat and mustard plants. The Environmentalist. 29(4): 398-404. https://doi.org/10.1007/s10669-009-9218-4

JOSHI P. C. \& SWAMI A. 2009. Air pollution induces changes in photosynthetic pigments of selected plant species. Journal of Environmental Biology. 30: 295-298.

KONGJAIMUN A., SOMTA P., TOMOOKA N., KAGA A., VAUGHAN D. A. \& SRINIVES P. 2013. QTL mapping of pod tenderness and total soluble solid in yardlong bean [Vigna unguiculata (L.) Walp. subsp. unguiculata cV.-gr. sesquipedalis]. Euphytica. 189: 217-223.

KUMAR S., YADAV S. S., TRIPURA P. \& JATAV H. S. 2017. Use of phosphorus for maximization of mungbean (Vigna radiate L.) (Wilszeck) productivity under semi-arid condition of Rajasthan, India. International Journal of Current Microbiology Applied Science. 6: 612-617. https://doi.org/10.20546/ijcmas.2017.602.069

LAFRAGÜETA C., GARCÍA-CRIADO B., ARRANZ A. \& VÁZQUEZ-DE-ALDANA B. R. 2014. Germination of Medicago sativa is inhibited by soluble compounds in cement dust. Environmental Science and Pollution Research. 21(2): 1285-1291.

ŁUKOWSKI A., POPEK R. \& KAROLEWSKI P. 2020. Particulate matter on foliage of Betula pendula, Quercus robur, and Tilia cordata: deposition and ecophysiology. Environmental Science and Pollution Research. https://doi.org/10.1007/s11356-020-07672-0

MANDRE M., KIOSEIKO J., OTS K. \& TUULMETS L. 1999. Changes in phytomass and nutrient partitioning in young conifers in extreme alkaline growth conditions. Environmental Pollution. 105(2): 209-220.

MEO S. A., AL-DREES A. M., ALMASRI A. A., AL-ROUQ F. \& AZEEM M. A. 2013. Effect of duration of exposure to cement dust on respiratory function on non-smoking cement mill workers. International Journal of Environmental Research Public Health. 10(1): 390-398. https://doi.org/10.3390/ijerph10010390

PANDEY D. D. \& KUMAR S. 1996. Impact of cement dust pollution on biomass, chlorophyll, nutrients and grain characteristics of wheat. Environment and Ecology. 14: 872-875.

PRASAD M. S. V. \& INAMDAR J. A. 1990. Effect of cement kiln dust pollution on groundnut (Arachis hypogea). Indian Botanical Contractor. 7(4): 159-162.

REHMAN S. A. \& IQBAL M. Z. 2009. Growth of Leucaena leucocephala (Lam.) De-wit in different soil compositions of Korangi and Landhi industrial areas of Karachi, Pakistan. Pakistan Journal of Botany. 41: 3125-3138. 
Raheela IQBAL \& al.

REUTERS. 2008. KARACHI Thu May 8, 2008 2:23am EDT Pakistan's Lucky Cement raises \$109 mln via GDRs. http://www.reuters.com/article/2008/05/08/lucky-idUSSIN19454200805 08 visited on 26 $6^{\text {th }}$ January, 2014.

SALAMA H. M. H., AL-RUMAIH M. M. \& AL-DOSAY M. A. 2011. Effects of Riyadh cement industry pollutions on some physiological and morphological factors of Datura innoxia Mill. plant. Saudi Journal of Biological Science. 18(3): 227-237.

SHAFIQ M. \& IQBAL M. Z. 1987. Plant sociology around the stone quarries and processing plants of Karachi and Thatta districts. International Journal of Ecology and. Environmental Sciences. 13: 33-35.

SHAFIQ M. \& IQBAL M. Z. 2012. Impact of Automobile Pollutants on Plants. LAMBERT Academic Publishing GmbH \& Co. KG Heinrich-Böcking-Str. 6-8, 66121, Saarbrücken, Germany, 132 pp.

SHAFIQ M., IQBAL M. Z., KABIR M. \& FAROOQI Z. 2019. Poison Land. Vegetation of disturbed and polluted areas in Pakistan. Strategic book publishing \& rights agency, U.S.A. 173 pp.

SHEN L., GAO T., ZHAO J., WANG L., WANG L., LIU L., CHEN F. \& XUE J. 2014. Renewable and Sustainable Energy Review. 34: 337-349.

TARO G. \& COMAN M. 2020. Aspects regarding the Romanian law in the field of ecological restoration of the industrial contaminated sites. Agricultural Science Research Journal. 10(2): 38-40.

WIN K. T. \& OO A. Z. 2016. Genotypic difference in salinity tolerance during early vegetative growth of cowpea (Vigna unguiculata L. Walp.) from Myanmar. Biocatalysts and Agricultural Biotechnology. 4: 449-455.

ZARGARI F. \& SHOAR H. H. 2008. Effects of various levels of cement dust on seed germination and early seedling growth in 2 cultivars of Helianthus annuus L. Research Journal of Biological. Sciences. 3(10): 1189-1193.

How to cite this article:

IQBAL R., IQBAL M. Z. \& SHAFIQ M. 2020. Impact of Portland cement on growth of bean crops. J. Plant Develop. 27: 121-127. https://doi.org/10.33628/jpd.2020.27.1.121 